Multi Colors: An International Journal of

Educational Research and Theory Vol 1(1), 2018-19

\title{
EFL Matriculation Exams for Deaf and Hard of Hearing Students:
}

\section{Polish and Israeli Experiences}

Ewa Domagała-Zyśk

John Paul II Catholic University of Lublin, Poland

Naomi Ganin Epstein

Ministry of Education / Yehud Comprehensive High-School, Israel

Correspondence concerning this article should be addressed to Professor Ewa Domagała-Zyśk;

email: ewadom@kul.lublin.pl

\begin{abstract}
In recent decades the significance of English as a lingua franca has been systematically growing: it is no longer simply the native language of some nations but is rather the language of science, business, education, and leisure around the world. Not surprisingly, there is a great demand to learn and know this language, which is mirrored by the importance placed on English teaching in national curricula and its presence as a mandatory exam subject in secondary education. While most students can follow such education programs smoothly, the group of $\mathrm{D} /$ deaf and hard of hearing learners $(\mathrm{D} / \mathrm{HoH})$ meet serious challenges when learning a foreign language without auditory input and require specific support and accommodations to meet the curricula requirements.

This paper presents the issue of teaching English as a foreign language to $\mathrm{D} / \mathrm{HoH}$ students in the context of their matriculation exams in two countries whose educational systems share some historical roots: Poland and Israel. The method used was document analysis in the framework of the cultural contexts of two educational systems. The results show similarities for educational expectations but also differences concerning the type and scope of accommodations for $\mathrm{D} / \mathrm{HoH}$ students. The analysis leads to pedagogical recommendations for improving the quality of $\mathrm{D} / \mathrm{HoH}$ students' education in these two countries.
\end{abstract}

Keywords

Deaf, Hard of hearing, EFL, Matriculation exam, Poland, Israel 


\section{Introduction}

Knowledge of English is an important part of culture in both Poland and Israel. Citizens of Poland are strongly convinced that foreign languages, especially English, are indispensable to success in education, work, and social life. Many Polish children begin learning English in kindergarten; both students and adults often learn languages in private language schools. After the 1989 transformation, Poland became a popular country for foreign businesses, and English is the official language of these international companies. Emigration is commonsince 2004 more than two million Polish people have emigrated, mainly to Western European countries. In Israel it has long been recognized that a command of both spoken and written English is not only necessary for both Hebrew and Arabic speakers to achieve successful careers in education, high-tech, commerce, and more, but also vital for entertainment and travel. The advent of the Internet has amplified these needs, leading to the launching of new programs to advance spoken skills in English (Revised English Curriculum Principles and Standards for Learning English as an International Language for All Grades [hereafter Revised English Curriculum], 2018).

Summing up, the globalization of science, education, economic markets, and leisure is a fact-therefore, those wishing to be a part of this movement, whether they are from Poland or from Israel, must know its language, English. Knowledge of English is necessary to participate in global trends regardless of where an individual hails from: Poland, Israel, or any other non-English-speaking country.

Systems of education in both Israel and Poland have undergone systematic changes aimed at improving the quality of education and specify the underlying values of their educational practices. In Poland the National Curriculum for Secondary Education (Podstawa Programowa, 2018) states that the aims of education at this level are to gain new knowledge that could serve as a basis for competencies, to master higher thinking and language skills, to develop and integrate students' interests and passions, to exercise tasks of formulating and expressing opinions, to develop critical thinking and social moral and aesthetic sensitivity, to understand and participate in culture, and to develop respect and passion for knowledge, together with skills for its practical implementation. Foreign-language education is a part of this program and aims at achieving the ability to communicate in a foreign language (in Poland, at least at the upper-intermediate level, according to the Common European Framework of Reference for Languages [CEFR]) concerning the above-mentioned spheres. In Israel the national curriculum has recently been revised and updated to respond to the ever-changing global transformation. The curriculum now includes benchmarks for the pre-foundation levels for young learners. The sections for secondary education include information communication technology skills (ICT) and higher-order thinking skills (HOTS) at all levels and domains, in order to enhance critical thinking skills (Revised English Curriculum, 2018).

In both countries analyzed in this paper, completing secondary education requires meeting the demands of matriculation exams-the Matura and the Bagrut. In Poland such exams are taken annually by about 300 and in Israel by about $400 \mathrm{D} /$ deaf and hard of hearing $(\mathrm{D} / \mathrm{HoH})$ students. The names for the exams in both languages are identical. "Bagrut" in Hebrew means exactly the same thing as "Matura" in Polish: to become mature. The name Bagrut is most likely a direct translation from the Polish, as parts of the original school system in Israel were based on the Jewish school system founded in Poland in the early 20th century. Report cards from those schools look extraordinarily similar to those used in Israel for many years.

This paper thus describes, compares, and contrasts the expectations for final language exams taken by high school students in Poland and in Israel and the accommodations provided in these exams for $\mathrm{D} / \mathrm{HoH}$ students. The research question is: What accommodations are provided for $\mathrm{D} / \mathrm{HoH}$ students taking foreignlanguage matriculation exams in Poland and Israel? The authors' teaching and research experience show that these exams and their accommodations share many aspects, which is interesting given the geographical and 
cultural distance between the two countries. Preliminary discussions with foreign-language teachers from both countries show that it might be profitable for both to acknowledge their similarities and differences and to recommend new solutions that might improve the educational options for $\mathrm{D} / \mathrm{HoH}$ students.

\subsection{Education of deaf and hard of hearing students in Poland and in Israel}

Mandatory education in Poland currently lasts for 10 years and consists of 1 year of preparatory class, 6 years of primary school, 3 years of lower secondary school, and 2 or 3 years of secondary school. Beginning in 2017, formal compulsory education lasts for 9 years and comprises 1 year of preschool education and 8 years of primary school. In Israel, standard education is mandatory between the ages of 3 and 18 (or upon the completion of 12th grade), although students in special education frameworks may study until age 21 . The Polish educational system holds a compulsory external exam in Grade 8, and its results influence admission to secondary schools. Students age 15 to 18 years can attend full-time compulsory education either in school settings (secondary schools) or in nonschool settings, where students follow vocational training offered by employers. In both Poland and Israel, matriculation exams mark the end of secondary education. The Matura is taken at the end of high school, and the Bagrut exams are spread over the 3 years of high school.

There are three educational frameworks for $\mathrm{D} / \mathrm{HoH}$ students in both Poland and Israel. In Poland they can attend mainstream (inclusive), integrative, or special schools, based on psychopedagogical assessment of their needs and their parents' consent. Nowadays more than $80 \%$ of $\mathrm{D} / \mathrm{HoH}$ students attend integrative and mainstream classes and enjoy the benefits of integration and inclusion. Nevertheless, the situation needs constant improvement. Even with the most modern hearing aids and cochlear implants, D/HoH students still have specific needs that must be met to provide them with the most effective education. Two types of changes are made in the education process: accommodations and modifications. Accommodations aim at changing the form of existing materials, teaching methods, techniques, and strategies to enable students with special needs to participate fully in the teaching and learning process; for example, the use of subtitles enables a child to watch a film together with their peers. Modifications, on the other hand, refer to changes in the teaching content, which usually means narrowing the facultative parts of the curriculum; for example, children with hearing problems might be waived from learning foreign-language pronunciation.

$\mathrm{D} / \mathrm{HoH}$ students in Poland have been required to learn a foreign language since 2001. Before that time, they were usually waived from language classes and rarely took the Matura exam. Since then, however, intensive teaching and research activities have been undertaken to provide high-quality foreign-language education for this group (Domagała-Zyśk, 2001, 2013a, 2013b, 2014, 2015, 2016a, 2016b; Harań \& Gulati, 2005; Podlewska, 2013, 2016). To give educators and novice foreign-language teachers the knowledge and skills necessary to support students who are $\mathrm{D} / \mathrm{HoH}$, researchers and experienced teachers from several countries formed the International Research Group on Teaching English as a Foreign Language to the Deaf and Hard of Hearing (http://www.kul.pl/ english-for-deaf-and-hard-of-hearing,art_74431.html), a platform for the exchange of teaching ideas and research results supporting the foreign-language education of $\mathrm{D} / \mathrm{HoH}$ students. Research topics are varied and include teaching and learning strategies (Domagała-Zyśk, 2013a, 2016a, 2016b; Epstein, 1990), reading comprehension (Sedláčková \& Fonioková, 2013), sign languages and Deaf identity in the process of foreign-language acquisition (Bajkó \& Kontra, 2008; Pritchard, 2013), the use of cued speech (Podlewska, 2013), English for vocational purposes (Ochse, 2013), and IT-assisted learning strategies (Domagała-Zyśk, 2013b; Nabiałek, 2013).

In Israel the first school for Deaf students accepted its first students more than 80 years ago (Plaut, 2007), whereas hard-of-hearing students received support in the regular school system. English was certainly not a priority in the early years, but it was taught. However, by 1986 the practice of pulling students out of English 
lessons to receive tutoring in other subjects officially ended. In 1988 the Ministry of Education published the first of a series of comprehensive documents detailing the accommodations that $\mathrm{D} / \mathrm{HoH}$ students were entitled to when taking exams in English and set the criteria for eligibility for these accommodations (Epstein, 1996). Educational counselors reach out to schools nationwide and provide information and support for implementing the accommodations and the underlying educational strategies needed for students to pass the exams.

\section{2. $\quad$ Method and Data}

This paper describes, compares, and contrasts the educational expectations for final language exams taken by high school students in Poland and in Israel and accommodations provided in them for $\mathrm{D} / \mathrm{HoH}$ students. The research question has been formulated as follows: What accommodations are provided for D/ $\mathrm{HoH}$ students for foreign-language matriculation exams in Poland and Israel? The authors used the methods of document analysis and educational action research (Palka, 2010; Wilczy】ska \& MichoØska-Stadnik, 2010). Both authors have taught English to $\mathrm{D} / \mathrm{HoH}$ students for several years, which helps them immensely to propose meaningful educational recommendations.

The two main educational documents analyzed during the study were National Curricula for English as a foreign language in secondary schools (the Polish Podstawa programowa, 2018, and the Israeli Revised English Curriculum, 2018). Apart from that, several examples of Matura and Bagrut tests from the years 2015-2017 were inspected, in both regular versions and versions for $\mathrm{D} / \mathrm{HoH}$ students.

\section{Results}

\subsection{Bagrut and Matura-General characteristics of the exams}

Students in the national Israeli school system are expected to spend 12 years at school, beginning at age six. Matriculation exams, known as Bagrut, are required in a wide range of subjects, and are taken mainly in the 11th and 12th grades. English as a foreign language is a mandatory subject, and most students begin studying it in the third grade. It is not possible to get a complete matriculation certificate at the end of high school without taking the English final exams at one of the three possible levels. It is mandatory for $\mathrm{D} / \mathrm{HoH}$ students as well. $\mathrm{D} / \mathrm{HoH}$ students are eligible for the same accommodations on the English Bagrut regardless of the framework in which they study-75\% are mainstreamed, and $14 \%$ study in self-contained classes in regular schools. These students take the exams at all levels, including the most advanced level. However, of the $14 \%$ whose multifaceted needs are so great as to require placement in a special education school, very few take the exam. The Bagrut exams test the four domains of language: reading comprehension, writing proficiency, speaking/oral proficiency skills, and listening comprehension. In addition there is a literature component. The exam has three levels, but all levels test all of these domains. Table 1 details how these domains, along with the literature component, are tested; they are described in detail in the next subsection. 


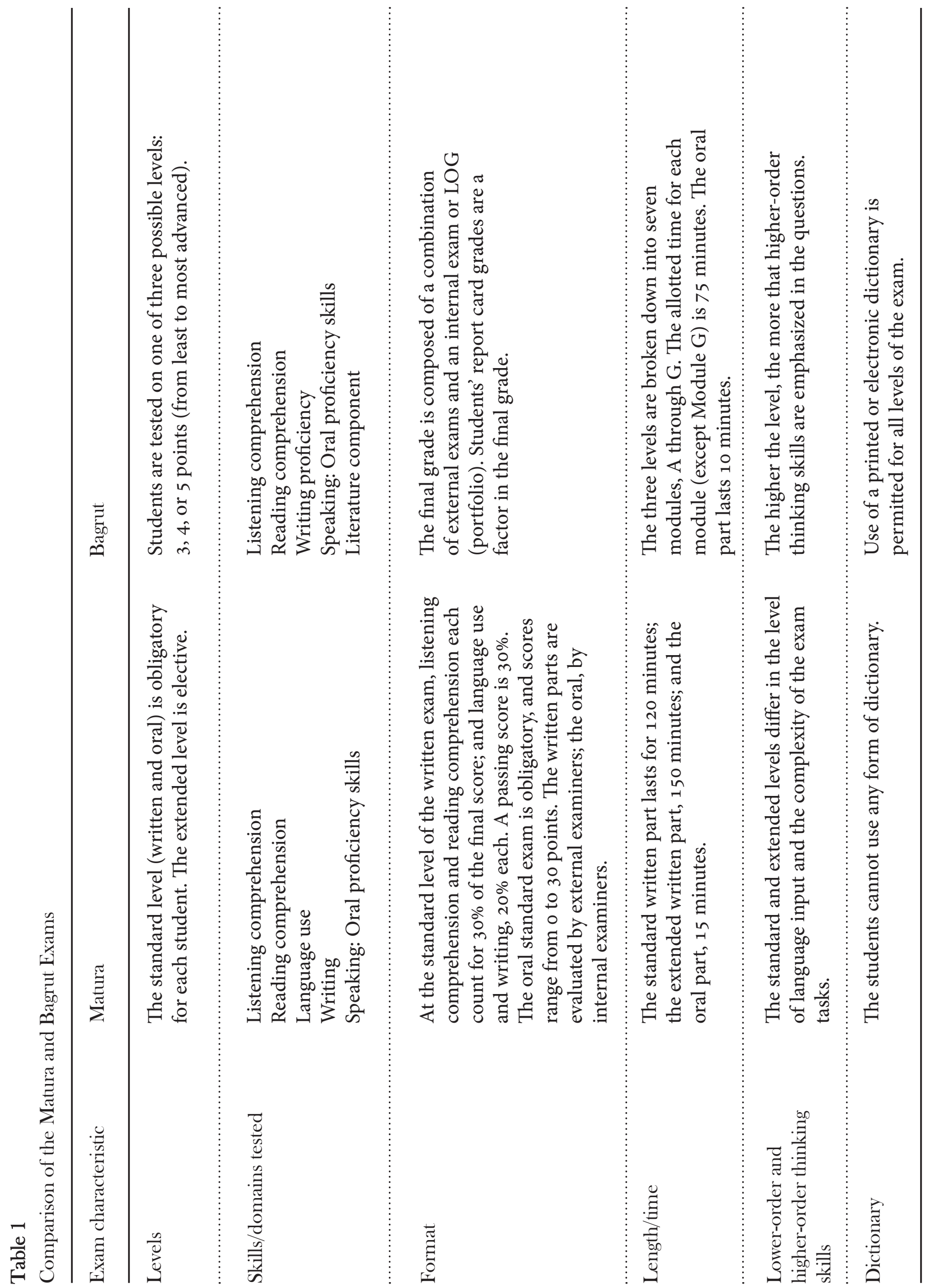


The Polish Matura exam consists of two parts: compulsory subjects and additional subjects. Each student is supposed to take three subjects at a standard level: Polish, mathematics, and a foreign language. Polish- and foreign-language exams are both written and oral. The oral part is assessed in the school, and the written part is assessed by external examiners. Apart from that, students should take at least one (and a maximum of five) elective "extended" exams, and there are many possibilities here. These include the above as well as biology, chemistry, geography, social studies, history, history of art, history of music, information technology, physics and astronomy, and another modern language or a language of an ethnic group. As of this writing, at most Polish universities and academies there are no entrance exams, so the results of the Matura exam determine students' choice of academic career.

Students with special educational needs have a full right to take Matura exams accommodated to their needs. Special exam sheets are prepared for (a) D/HoH students, (b) blind students, and (c) students with Asperger syndrome. Students with a diagnosis of dyslexia have a right to have their exam accommodated; that is, they can have more time to write it, work in a special room, and/or have their written work checked according to special rules that do not take spelling or syntax errors into account.

\subsection{Foreign-language exams in Bagrut and Matura}

As stated, the two foreign-language matriculation exams, Matura and Bagrut, share many similarities.

A foreign-language exam at the standard level should be taken by each Matura candidate, and there are several languages to choose from; nevertheless, English is the choice of more than $94 \%$ of students. The Matura language exam consists of the following: (a) listening comprehension, which counts toward 30\% of the final result; (b) reading comprehension (30\%); (c) language use (20\%); and (d) writing (20\%). Students are not permitted to use a dictionary or any other form of support during the exam. The Bagrut exam on each level ( 3,4 , and 5 points) is broken down into three modules. The domains social interaction, access to information, presentation, and appreciation of language and culture are tested throughout the three modules, which together form the final grade. The components of these domains are detailed below.

\subsubsection{Testing reading comprehension}

On the Bagrut exam, reading comprehension is tested in all sections and levels. Comprehending the texts in Module A requires mainly straightforward, lower-order thinking skills, using limited vocabulary and basic grammatical forms. At the highest level, the reading passages consist of advanced vocabulary items and grammatical structures, and the questions focus mainly on HOTS, such as identifying the main idea, inference, and cause and effect. The complexity of the text and the reading-comprehension questions increases fairly gradually from Module A to Module G. Reading comprehension is also evaluated, albeit differently, in the literature component of the Bagrut. In each of the Bagrut's three levels (the 3-, 4-, and 5-point levels), 30\% of the grade is devoted to the study of literature. In the two higher levels (4 points and 5 points, respectively), students study six authentic literary pieces (poems, short stories, and a play/novel) and either are tested on comprehension or hand in a log reflecting their work. The comprehension questions assess both lower-order and higher-order thinking skills. On the lowest level (3 points), the students study only three pieces, and these can be simplified texts. Here, the emphasis is on lower-order thinking skills. The reading section of the Polish Matura foreign-language exam consists of three or four texts which can be either authentic or slightly modified. Their combined length should be 900 to 1,200 words. Students are supposed to complete a set of "closed" tasks based on the text content (e.g., false/true, multiple choice) 


\subsubsection{Testing language use}

This section of the matriculation exam is explicitly designed only in the Polish Matura and is meant to examine the scope of using vocabulary and grammar language elements. It consists of two or three tasks based on authentic or slightly modified short texts and sentences, in the form of closed questions (true/false, multiple choice, etc.). Unlike the Polish model, on the Bagrut exam, grammar and vocabulary are tested in the essaywriting and as part of the reading-comprehensions tasks-points are deducted for grammatical and lexical errors when answering the questions.

\subsubsection{Testing writing proficiency}

This domain is tested in the Bagrut exam both directly and indirectly. For the explicit writing tasks, students are required to write about a certain topic on the Module $\mathrm{C}$ exam (70-90 words, 30 points) and a complete essay on the Module G exam (120-140 words, 40 points). The writing task is graded according to four elements: content, vocabulary (level, complexity, and correct usage), language (grammar), and mechanics (punctuation, spelling, use of capital letters, etc.). For the indirect writing assessment, on the reading-comprehension sections of the exams, students are also assessed on the accuracy of their grammar in responding to questions. This applies to responses to open-ended questions and to questions requiring sentence completion (continuing a provided stem). Polish students are supposed to write an 80- to 130-word text of everyday use (a letter, an e-mail, and an Internet post) in which they show their ability to describe, express their opinions about, and show advantages and disadvantages of different solutions. The text is assessed for its content and language elements, language fluency, and accuracy.

\subsubsection{Testing listening comprehension}

Students taking Modules $\mathrm{A}$ or $\mathrm{E}$ of the Bagrut are required to listen to a short talk and to answer questions about what they heard. They have two opportunities to hear the spoken text, which is read once by a man and once by a woman. The listening-comprehension section of the Polish Matura exam consists of three or four tasks lasting for about 20 minutes. The texts recorded could be authentic or slightly modified and are presented by native foreign-language users. Students must answer several closed questions (multiple choice, false/true, etc.).

\subsubsection{Testing oral proficiency}

On the Bagrut exam, students have an introductory conversation with the examiner before moving on to presenting and discussing the project they've prepared beforehand. The Polish exam has an obligatory oral part, and it should be approximately 15 minutes long. Students are required to perform four tasks: an introductory conversation with the examiner, a role-playing activity based on the stimuli and examiners' additional questions, describing a picture and answering the examiners' questions connected with it, and language reaction to a visual stimuli and a short conversation with the examiner on the topics.

\section{Accommodations for $\mathrm{D} / \mathrm{HoH}$ Students}

Both the Matura and the Bagrut have accommodations for $\mathrm{D} / \mathrm{HoH}$ students. The standard version of the Matura lasts 120 minutes and consists of reading comprehension, language use, and writing parts (there is no literature component). Accommodated versions are provided for students upon request, on the basis of their medical documentation verifying their hearing impairment. Students with a mild documentation verifying their hearing impairment. Students with a mild hearing loss can ask for special recordings (with a slower pace of 
speaking and longer pauses) or for the opportunity to take the test in a special room, using headphones that facilitate listening. The right to receive accommodations on the Bagrut exam is also based on medical documentation attesting to the severity of the hearing loss. Students with a mild hearing loss may have extra time to hear the listening-comprehension task, to be tested in a quiet room, and to have spelling mistakes ignored. All other accommodations, as detailed below, relate to students with a bilateral hearing loss of more than 36 decibels in both ears.

Both exams aim to check mainly reading comprehension. In the reading-comprehension section of the Matura exam, D/HoH students read three or four texts that have been accommodated to their specific needs. Because it is forbidden to use dictionaries during the whole exam, accommodations allow for adaptations to the text itself. The text can be either authentic or adapted. Compared with the regular test version, here the sentences are shorter, structures are generally the most common and regular ones, and some vocabulary items can be replaced with their more common synonyms. In multiple-choice tasks that assess text comprehension, the number of options is limited (e.g., three instead of four). The authors of the text also respect issues of cultural awareness and avoid content that $\mathrm{D} / \mathrm{HoH}$ students might find difficult to experience (e.g., there are generally no texts about music or other kinds of listening activities). On the Bagrut exam, the reading-comprehension passages and questions are not modified in any way for $\mathrm{D} / \mathrm{HoH}$ students. However, students are permitted to use an electronic dictionary (as of 2018, all students in the school system are allowed to use one), and they receive an automatic 10-point bonus. In addition, spelling mistakes are ignored and extra time is given. Only on Module $\mathrm{A}$ is the replacement for the listening-comprehension task a unique reading passage written specifically for these students.

As mentioned above, the language-use section appears only in the Matura, and it aims to check a student's abilities to use language in context. In the original version, students are asked to fill in the gaps, to choose the right paraphrasing of a sentence, or to perform multiple-choice tasks to complete a text. In the accommodated version, the types of tasks are the same but the exercises are shorter, the grammar structures are more regular, and the number of options in multiple-choice tasks is reduced. The last task of this part is designed typically for $\mathrm{D} / \mathrm{HoH}$ users-it checks communication structures that might be used in both oral and written communicationand students are asked to complete short dialogues using the correct language structure.

Writing is evaluated slightly differently in the two exam frameworks. In the regular writing proficiency section of the Matura exam, students are asked to write an 80- to 130-word text, such as a letter, e-mail, or blog entry. The topic is connected to everyday situations, instruction is given in Polish, and there are four points to be developed. The $\mathrm{D} / \mathrm{HoH}$-accommodated version consists of two writing tasks: a picture description, with a visual and a set of four questions to be answered, and the writing of a text of 50 to 100 words on a given topic, with three points to be discussed. The written parts of the Matura exam are evaluated by external examiners, and generally the criteria for regular and accommodated versions are the same, with some exceptions for vocabulary range and text structure. The examiners attend special practical training to assess the language difficulties connected with hearing loss and sign-language interference and to properly evaluate the content of $\mathrm{D} / \mathrm{HoH}$ students' writing. On the most advanced level of the Bagrut exam, Module G, students are required to write a 120- to 140-word essay, just like their hearing peers, but no points are deducted for mechanics (spelling, use of capital letters, etc.). On Module $\mathrm{C}$, which denotes a lower level, $\mathrm{D} / \mathrm{HoH}$ students get an easier writing task. Students must write a short letter describing a past event or an experience they are having (such as studying abroad). The required length of the writing task is only 35 words, whereas the standard requirement is 90 words. On the literature component 
of the Bagrut exam, students can submit shorter post-reading written tasks or replace them with visual creations (slideshows, drawings, etc.). On the log version, students may also hand in multiple drafts of their work. The exam accommodations for $\mathrm{D} / \mathrm{HoH}$ students on both exams are listed in Table 2.

Table 2

Accommodations for Deaf / Hard of Hearing students

\begin{tabular}{|c|c|c|}
\hline Accommodation & Matura & Bagrut \\
\hline Extra time & Yes & Yes \\
\hline Listening-exempt & Yes & Yes \\
\hline Exam in quiet room & Yes & Yes \\
\hline Oral exam-exempt on request & Yes & Yes \\
\hline Dictionary use & No & Yes \\
\hline $\begin{array}{l}\text { Translation of some vocabulary } \\
\text { items in the reading part }\end{array}$ & Yes & No \\
\hline Bonus points & No & Yes, 10 points \\
\hline Spelling mistakes ignored & Yes, limited & Yes \\
\hline Simplified reading passages & Yes, standard level & $\begin{array}{l}\text { No, except for the task that } \\
\text { replaces the listening on } \\
\text { Module A }\end{array}$ \\
\hline $\begin{array}{l}\text { Use of simplified grammatical } \\
\text { structure \& vocabulary }\end{array}$ & Yes & $\begin{array}{l}\text { No, lower levels simplified for } \\
\text { all students nationwide }\end{array}$ \\
\hline $\begin{array}{l}\text { Exams checked by specially } \\
\text { trained examiners }\end{array}$ & Yes & No \\
\hline Adjusted evaluation criteria & Yes & No \\
\hline Shorter writing tasks & Yes, standard level & Yes, lower level only \\
\hline
\end{tabular}

\section{Discussion}

The analysis and comparison done by the authors originally working with these students in their home countries was interesting and profitable, and the results may benefit teachers, students, and researchers. In both Israel and Poland the number of $\mathrm{D} / \mathrm{HoH}$ students successfully meeting the requirements of EFL matriculation exams has been growing, as has the number of students taking the exams at advanced levels. The positive impact of early screening and unique educational programs, along with cutting-edge audiological rehabilitation technology, is clearly seen in such a comparison between countries. Not only was Israel an early adopter of neonatal screening and early intervention programs for the Deaf (the first official program for toddlers, "Micha," opened its doors in 1953), which led to the use of hearing aids, and later cochlear implants (CIs) at a young age, but also English became a mandatory subject for these students in 1985. In recent years Poland has adopted similar practices-neonatal screening programs began in 1992, and as of this writing $96 \%$ of newborns have their hearing tested during the first days of life. The number of modern digital hearing-aid users is also growing. The first CI operation was performed in Poland in 1992, the total number of CI users is an estimated 2,500 childre 
as of this writing, and the tendency toward early implantation is a growing trend there.

$\mathrm{D} / \mathrm{HoH}$ students from both countries are offered the same quality of education as their hearing peers, and teachers do their best to prepare them effectively for school exams. The matriculation-exam formats are accommodated and reflect similar teaching practices in both countries: students get support in reading tasks either by having the opportunity to use a dictionary (Israel) or by having the texts accommodated (Poland), and either the evaluation criteria for writing are adjusted (Poland) or spelling mistakes do not influence the final mark (Israel). In both countries, students might be exempted from the oral part of the exam, and there is no listening part. Such accommodations seem to be fair and to help $\mathrm{D} / \mathrm{HoH}$ students surmount the educational barriers.

In recent decades, an enormous effort has been made in both countries to include $\mathrm{D} / \mathrm{HoH}$ students in their educational systems. Till the end of the 1990s, D/HoH students usually ended their education at the level of primary or vocational school, where they could get only some basic job skills. Inclusion strategies based on teaching and learning accommodations made it possible for $\mathrm{D} / \mathrm{HoH}$ students to enter secondary schools and pass the matriculation exams, which is a gate to higher education. In Poland today more than 1,500 D/HoH persons study at universities and other institutions of higher education.

This strategy of accommodating foreign-language education for $\mathrm{D} / \mathrm{HoH}$ students should be perceived as a practical realization of the right of students with special education needs to quality education and inclusion (United Nations, 2006).

\section{Conclusion}

This paper aimed at answering the question "What accommodations are provided for $\mathrm{D} / \mathrm{HoH}$ students for foreign-language matriculation exams in Poland and Israel?" Comparison of these two formats showed, first, similar educational approaches, which could be described as supporting $\mathrm{D} / \mathrm{HoH}$ students' foreign-language education through accommodations to the matriculation exams. The types of accommodations were generally similar and could serve as a model for other countries interested in improving their strategies.

The analysis leads to some teaching recommendations. First, teachers should ensure that they provide the above accommodations well not only during the exams but also during regular teaching practice. Second, D/HoH students' needs should be regularly assessed, as they change over time-the group of students using listening and speaking in a foreign language has been growing; therefore, there is a need to create exam formats that address these skills: listening tasks recorded in an accommodated way, exam conversations with the use of electronic devices, and so forth. Third, a wider understanding of the nature of hearing loss is necessary in both countries, and it may widen the scope of accommodations used. Hearing loss is a language disability-that is why it is necessary to adjust the linguistic aspects of the exam elements, for example by providing students with dictionaries (in paper or electronic form) or adapting the texts. In Israel $\mathrm{D} / \mathrm{HoH}$ students have been using bilingual dictionaries for the last 35 to 40 years, which has proved significantly effective in increasing the number of students who can pass the exams. An example of this was most clearly seen when comparing the achievements of $\mathrm{D} / \mathrm{HoH}$ students in mainstream classes and in self-contained classes. While the students in the self-contained classes were defined overall as "weaker" students, their results were on par with those who studied in the mainstream classes. One of the main factors that contributed to this was the explicit instruction tailored to these students in general and on how to use a dictionary effectively (Epstein, 1996). 


\section{References}

Bajkó, Á., \& Kontra, E. H. (2008). Deaf EFL learners outside the school system. In J. Kormos \& E. H. Kontra (Eds.), Language learners with special needs: An international perspective (pp. 158-188). Clevedon, England: Multilingual Matters.

Domagała-Zyśk, E. (2001). O uczeniu języka angielskiego uczniów z uszkodzeniem słuchu. Języki Obce w Szkole, 7, 106-110.

Domagała-Zyśk, E. (2013b). Using technology to teach English as a foreign language to the deaf and hard of hearing. In E. Vilar Beltrán, C. Abbott, \& J. Jones (Eds.), Inclusive language education and digital technology (pp. 84-102). Bristol, England: Multilingual Matters. https://doi.org/10.21832/9781847699749-007

Domagała-Zyśk, E. (2013a). Written English of Polish deaf and hard of hearing grammar school students. In E. Domagała-Zyśk (Ed.), English as a foreign language for the deaf and hard of hearing persons in

Europe

(pp. 163-180). Lublin, Poland: Wydawnictwo KUL.

Domagała-Zyśk, E. (2014). Teaching English as a foreign language to a student with hearing loss combined with slight autistic disorders. In E. Domagała-Zyśk (Ed.), Developing language competence of people with hearing and speech disorders (pp. 162-177). Lublin, Poland: Wydawnictwo KUL.

Domagała-Zyśk, E. (2015). Beliefs about learning English as a foreign language-Experience of deaf and hard-ofhearing Polish adolescents. Studia Anglica Resoviensia, 90, zeszyt 12, s. 16-29. (7 pkt)

Domagała-Zyśk, E. (2016a). Teaching English as a second language to deaf and hard-of-hearing students. In M.

Marschark \& P. E. Spencer (Eds.), The Oxford handbook of deaf studies in language (pp. 231-246).

New York, NY: Oxford University Press.

Domagała-Zyśk, E. (2016b). Vocabulary teaching strategies in EFL classes for deaf and hard of hearing students.

In E. Domagała-Zyśk \& E. H. Kontra (Eds.), English as a foreign language for deaf and hard-of-hearing persons: Challenges and strategies (pp. 135-152). Newcastle upon Tyne, England: Cambridge Scholars. Epstein, N. (1990). Teaching English to hearing impaired children. English Teachers Journal, 40, 33-37.

Epstein, N. (1996). The effect of educational setting on hearing impaired pupils' matriculation grades in English (Master's thesis). Tel-Aviv University, Israel.

Harań, B., \& Gulati, S. (2005). Teaching English to deaf students at the University of Podlasie. Nauczanie języka angielskiego niesłyszących studentów w Akademii Podlaskiej. In B. Harań (Ed.), Kształcenie studentów niepełnosprawnych w zakresie języków obcych (pp. 93-106). Siedlce, Poland: Wydawnictwo Akademii Podlaskiej.

Nabiałek, A. (2013). From a blackboard to an interactive whiteboard: Teaching English as a foreign language to deaf and hard of hearing students at Adam Mickiewicz University in Poznań. In E. Domagała-Zyśk (Ed.), English as a foreign language for deaf and hard of hearing persons in Europe (pp. 197-206). Lublin, Poland: Wydawnictwo KUL.

Ochse, E. (2013). English for specialized / specific purposes and the Deaf professional: The SignMedia Project. In E. Domagała-Zyśk (Ed.), English as a foreign language for deaf and hard of hearing persons in Europe (pp. 77-91). Lublin, Poland: Wydawnictwo KUL.

Palka, S. (2010). Podstawy metodologii badań w pedagogice. Gdańsk, Poland: GWP.

Plaut, A. (2007). The history of educational frameworks for students with hearing impairments in Israel 19322005. Israel: The MOFET Institute. 
Podlewska, A. (2013). The use of cued speech within an empirically-based approach to teaching English as a foreign language to hard of hearing students. In E. Domagała-Zyśk (Ed.), English as a foreign language for deaf and hard of hearing persons in Europe (pp. 181-196). Lublin, Poland: Wydawnictwo KUL.

Podlewska, A. (2016). The use of cued speech to support the development of verbal language skills in English language instruction for deaf and hard-of-hearing students. In E. Domagała-Zyśk \& E. H. Kontra (Eds.), English as a foreign language for deaf and hard-of-hearing persons: Challenges and strategies (pp. 23-40). Newcastle upon Tyne, England: Cambridge Scholars.

Podstawa programowa kształcenia ogółnego dla liceum, technikum I branżowej szkoły II stopnia (National Curriculum for Secondary Education). (2018). Retrieved January 2, 2018, from https://men.gov.pl/ ministerstwo/informacje/nowa-podstawa-programowa-dla-liceum-technikum-i-branzowej-szkoly-ii-stopniapodpisana.html

Pritchard, P. (2013). Teaching of English to deaf and severely hard-of-hearing pupils in Norway. In E. DomagałaZyśk (Ed.), English as a foreign language for deaf and hard of hearing persons in Europe (pp. 113-134). Lublin, Poland: Wydawnictwo KUL.

Revised English Curriculum Principles and Standards for Learning English as an International Language for All Grades. (2018, January). State of Israel, Ministry of Education. Retrieved May 2, 2018, from http:// meyda.education.gov.il/files/Mazkirut_Pedagogit/English/curriculum2018.pdf

Sedláčková, J., \& Fonioková, Z. (2013). Reading strategy instruction for deaf learners of English: Definitions, contexts and implications. In E. Domagała-Zyśk (Ed.), English as a foreign language for deaf and hard of hearing persons in Europe (pp. 135-152). Lublin, Poland: Wydawnictwo KUL.

United Nations. (2006). Convention on the Rights of Persons with Disabilities. Treaty Series, 2515, 3. Retrieved May 2, 2018, from https:/www.un.org/development/desa/disabilities/convention-on-the-rights-ofpersons- with-disabilities.html

Wilczyńska, W., \& Michońska-Stadnik, A. (2010). Metodologia badań w glottodydaktyce. Kraków, Poland: Avalon. 